Акимов О.О., Бояров В.Т., Бурсала О.Л., Кузін С.Є., Жданюк М.М. Державний науководослідний інститут випробувань і сертифікаиії озброєнь та військової техніки

\title{
ПРО ВИЗНАЧЕННЯ ПЛАВНОСТІ ХОДУ БРОНЕАВТОМОБІЛІВ ЧАСТОТНИМ МЕТОДОМ
}

У статті проаналізовані методи оцінки плавності руху автомобільної техніки. Запропонований метод визначення плавності руху автомобіля частотним методом. Динамічна модель вільних коливань автомобіля дозволяє визначити чотири частоти власних коливань при його повній та спорядженій масі. Нижчу частоту власних коливань рекомендується використати для оцінки плавності руху бронеавтомобіля. Розрахунки виконані для бронеавтомобіля БРДМ-2Л1. Результати випробувань підтвердили дієвість запропонованого методу.

Ключові слова: плавність руху бронеавтомобілів, частоти власних коливань, динамічна модель бронеавтомобіля, оцінка плавності руху бронеавтомобілів.

Розробка нових видів бронетехніки неможлива без визначення динамічних характеристик, які впливають на їх експлуатаційні характеристики.

Модернізація існуючої бронетехніки веде до зміни інерційних параметрів корпусу, положення центру маси, пружних параметрів шасі та шин, що може призвести до суттєвого погіршення динамічних характеристик бронеавтомобіля.

Під час руху броньованої машини по дорозі з нерівною поверхнею вона здійснює вимушені коливання, величина яких залежить від динамічних властивостей автомобіля, швидкості його руху та профілю поверхні дороги. Важливою характеристикою бронеавтомобіля $є$ плавність ходу, яка визначає комфортабельність екіпажу, впливає на керованість автомобілем, підвищує точність ураження цілі під час руху.

Оцінка плавності ходу автомобіля може проводитися при дорожніх чи лабораторних випробуваннях.

Дорожні випробування потребують ділянки дороги 3 твердим покриттям та спеціальним контрольованим профілем довжиною від 250 до 1000 м під час руху автомобіля від 10 до 90 км/год.

У якості характеристик поверхонь доріг приймаються спектральні щільності мікропрофілю та інші показники, що визначають ступінь впливу дороги на автомобіль.

Лабораторні випробування потребують спеціальних вібростендів, які здатні генерувати низькочастотну вібрацію значної потужності.

Під час випробуваннь на плавність ходу використовують низькочастотні вимірювачі вібрації, 3 можливістю реєстрації параметрів вібрації та їх спектрального складу в характерних точках бронеавтомобілів.

Жорсткі вимоги до умов випробувань, спеціальних вимірювальних засобів, приводять до того, що експериментальні випробування на плавність ходу проводяться 3 певними ускладненнями.

Проблемі нормування вібронавантаження бронетехніки та персоналу присвячені чисельні нормативно-технічні документи: ИСО 2631-78; ГОСТ 12.1.012-90, OCT 37.001.275-84, OCT 37.001.291-84, ГОСТ В. 21951-76, РЕО CВ - 80.

У нормативно-технічних документах наведений діапазон частот та встановлені граничні норми вимушених коливань бронеавтомобілів, які регламентують плавність ходу автомобілів.

Визначення параметрів коливань автомобілів.

Дослідженню динамічних характеристик бронеавтомобілів присвячена чисельна технічна література [1], [2], [3]. 
Різні аспекти випробувань автомобілів знайшли відображення у наступних технічних виданнях [4], [5].

Об'єктивно оцінити коливання й плавність ходу автомобіля можна, знаючи переміщення, віброшвидкість, віброприскорення, частоти власних коливань водія, спектральний склад параметрів вібрації, інтенсивність згасання амплітуд коливань пасажирів і вантажів.

Практика доводить: якщо частота коливання корпусе важкої машини лежить у межах до 1,3...1,7 Гц, то машина має задовільну плавність ходу [3], [4].

Використання нижчої частоти власних коливань бронеавтомобіля для оцінки плавності його ходу є значним спрощенням випробування машин на плавність ходу.

При проведенні випробувань машини оцінюються масо-габаритні параметри машини, на основі яких визначають іiі інерційні параметри, жорсткісні параметри підвіски, шин.

Найбільш важливими параметрами плавності ходу машини вважаються, у поздовжньому напрямку руху машини (підплигування та галопування), тому можливе використання спрощеної динамічної моделі, яка описує вертикальні та кутові коливання у вертикальній площині [1].

Динамічна модель має у своєму складі:

- корпус машини (масою $M$ та моментом інерції $I$ навколо горизонтальної осі перпендикулярної відносно напряму руху, опертий на ресори;

- передній та задній мости з колесами масами $m_{1}, m_{2}$ відповідно, опертими на шини.

Рух механічної системи описується чотирма узагальненими координатами: переміщення центру маси підресореного корпусу у вертикальному напрямку $Z$, кутом нахилу головної центральної осі інерції (ГЦОІ) корпусу у повздовжньому напрямку $\varphi$, переміщенням центрів мас переднього та заднього мостів у вертикальному напрямку $Z_{1}, Z_{2}$ відповідно.

Кінетична енергія механічної системи визначиться виразом:

$$
T=\frac{1}{2} M \times \dot{Z}^{2}+\frac{1}{2} I_{y} \dot{\varphi}^{2}+\frac{1}{2} m_{1} \dot{Z}_{1}^{2}+\frac{1}{2} m_{2} \dot{Z}_{2}^{2} .
$$

Потенційна енергія механічної системи, яка складається 3 потенційної енергії деформованих ресор та шин коліс у вертикальному напрямку, визначається виразом:

$$
\Pi=1 / 2\left(C_{k 1} \times Z_{1}^{2}+C_{k 2} \times Z_{2}^{2}+C_{r l}\left(Z-h_{1} \times \varphi-Z_{1}\right)^{2}+C_{r 2}\left(Z+h_{2} \times \varphi+Z_{2}\right)^{2}\right),
$$

де $C_{k 1}, C_{k 2}$ - жорсткість двох шин передніх та задніх коліс відповідно;

$C_{r 1}, C_{r 2}-$ жорсткість двох ресор передніх та задніх мостів відповідно;

$h_{l}, h_{2}$ - відстань від центру маси корпусу до переднього та заднього мостів відповідно.

Аналогічно, [2], використовуючи вирази кінетичної та потенційної енергій, за допомогою рівняння Лагранжа другого роду, одержимо систему диференціальних рівнянь другого порядку, що описує вільні коливання механічної системи у наступному вигляді:

$$
\left\{\begin{array}{l}
M \times \ddot{Z}+\left(C_{r 1}+C_{r 2}\right) Z-\left(C_{r 1} h_{1}-C_{r 2} h_{2}\right) \varphi-C_{r 1} \times Z_{1}-C_{r 2} \times Z_{2}=0, \\
I \times \ddot{\varphi}-\left(C_{r 1} h_{1}-C_{r 2} h_{2}\right) Z+\left(C_{r 1} h_{1}^{2}-C_{r 2} h_{2}^{2}\right) \varphi-C_{r 1} \times h_{1 \times} \times Z_{1}-C_{r 2} \times h_{2} \times Z_{2}=0 \\
m_{1} \times \ddot{Z}_{1}-C_{r 1} \times Z-C_{r 1} \times h_{1} \times \varphi+C_{k 1} \times Z_{1}=0 \\
m_{2} \times \ddot{Z}_{2}-C_{r 2} \times Z-C_{r 2} \times h_{2} \times \varphi+C_{k 2} \times Z_{2}=0,
\end{array}\right.
$$

де $\mathrm{M}$ - маса броньованої машини;

I - екваторіальний момент інерції;

$\mathrm{C}_{\mathrm{p}}, \mathrm{C}_{\mathrm{Z}}$ - жорсткість передніх коліс і ресор у вертикальному напрямку; 
$C_{p}, C_{z}-$ жорсткість задніх коліс і ресор у вертикальному напрямку;

$h_{p}, h_{z}-$ відстань від центру маси машини до передніх коліс та задніх відповідно.

Математична модель дозволяє визначити чотири значення частот власних коливань у вертикальному напрямку.

Визначення частот власних коливань машини зводяться до стандартної задачі [1]:

$$
M \times \bar{x}=\lambda \times K \bar{x}
$$

де $\lambda=1 / \omega^{2}$;

М - матриця інерційних коефіцієнтів;

К - матриця коефіцієнтів жорсткості.

Методика була перевірена на модернізованому бронеавтомобілі БРДМ-2Л1.

Визначення частот власних коливань машини звелося до стандартної задачі в пакеті Machcad 15. У результаті проведення розрахунків одержані наступні оцінки:

для спорядженої маси виробу - $\omega_{1}=0,617$ рад $/ \mathrm{c} ; \omega_{2}=0,896 \mathrm{paд} / \mathrm{c} ; \omega_{3}=6.436 \mathrm{paд} / \mathrm{c}$; $\omega_{4}=6,437$ рад/с.

для повної маси виробу - $\omega_{1}=0,581 \mathrm{paд} / \mathrm{c} ; \omega_{2}=0,648 \mathrm{paд} / \mathrm{c} ; \omega_{3}=6.436 \mathrm{paд} / \mathrm{c}$; $\omega_{4}=6,437$ рад/c.

Значення першої частоти власних коливань для спорядженої та повної маси виробу підтверджує задовільну плавність ходу виробу. Результати визначальних відомчих випробувань підтвердили отримані оцінки. Результати розрахунку дозволяють зробити висновок, що запропонований теоретично-експериментальний метод може бути використаний на стадії випробування для оцінки плавності ходу бронеавтомобіля, що значно скоротить час та витрати на його випробування.

\section{СПИСОК ЛІТЕРАТУРИ}

1. Вонг Дж. Теория наземных транспортных средств. / Дж. Вонг. - М.: Машиностроение, 1982. -284 с.

2. Смирнов Г.А. Теория движения колесных машин. / Г.А. Смирнов. - М.: Машиностроение, 1990. - 352 с.

3. Балабин И.В., Куров Б.А., Лаптев С.А. Испытания автомобилей. - 2-е изд., перераб. и доп. - М.: Машиностроение, 1988. - 192 с.

4. Безверхий С.Ф. Основы технологии полигонных испытаний и сертификация автомобилей. / С.Ф. Безверхий, Н.Н. Яценко. - М.: Изд-во стандартов, 1996. - 600 с.

5. Яценко Н.Н. Форсированные полигонные испытания автомобилей. / Н.Н. Яценко. - М.: Машиностроение, 1984. - 327 с.

\section{Акимов Олександр Олександрович}

кандидат технічних наук, старший науковий співробітник Державного науково-дослідного інституту випробувань і сертифікації озброєння та військової техніки, Чернігів, Україна

https://orcid.org/0000-0002-4443-8755

+38050-385-01-79

\section{Бояров Володимир Тихонович}

науковий співробітник Державного науководослідного інституту випробувань і сертифікації озброєння та військової техніки, Чернігів, Україна https://orcid.org/0000-0002-5824-0678 +38097-757-56-72

\section{Oleksandr A kymov}

Candidate of Technical Sciences, Senior Researcher of State Scientific Research Institute of Armament and Military Equipment Testing and Certification, Chernihiv, Ukraine https://orcid.org/0000-0002-4443-8755 +38050-385-01-79

\section{Volodymyr Boiarov}

Researcher of State Scientific Research Institute of Armament and Military Equipment Testing and Certification, Chernihiv, Ukraine https://orcid.org/0000-0002-5824-0678 $+38097-757-56-72$ 


\section{Бурсала Олександр Леонідович}

кандидат технічних наук, старший науковий співробітник, начальник науково-дослідного відділу Державного науково-дослідного інституту випробувань і сертифікації озброєння та військової техніки, Чернігів, Україна

https://orcid.org/0000-0002-8523-8987

+38099-478-89-25

\section{Кузін Сергій Свгенович}

Начальник науково-дослідної лабораторії Державного науково-дослідного інституту випробувань i сертифікації озброєння та військової техніки, Чернігів, Україна https://orcid.org/0000-0003-2562-7902 0462-67-94-29

\section{Жданюк Микола Миколайович}

старший науковий співробітник Державного науково-дослідного інституту випробувань i сертифікації озброєння та військової техніки, Чернігів, Україна https://orcid.org/0000-0002-0339-5445 +38050-647-19-55

\section{Olexandr Bursala}

Candidate of Technical Sciences, Senior Researcher, Chief of Section of State Scientific Research Institute of Armament and Military Equipment Testing and Certification, Chernihiv, Ukraine https://orcid.org/0000-0002-8523-8987 +38099 478-89-25

\section{Sergii Kuzin}

Chief of Laboratory of State Scientific Research Institute of Armament and Military Equipment Testing and Certification, Chernihiv, Ukraine https://orcid.org/0000-0003-2562-7902 0462-67-94-29

\section{Mykola Zhdaniuk}

Senior Researcher of State Scientific Research Institute of Armament and Military Equipment Testing and Certification, Chernihiv, Ukraine https://orcid.org/0000-0002-0339-5445 +38050-647-19-55

\section{ON THE DETERMINING OF THE ARMORED VEHICLES' SMOOTHNESS OF THE RIDE BY THE FREQUENCY METHOD}

O. Akymov, V. Boiarov, O. Bursala, S. Kuzin, M. Zhdaniuk

The development of new types of armored vehicles is impossible without determining the dynamic characteristics that affect their performance. The upgrading of existing armored vehicles leads to a change in the inertial parameters of the hull, the position of the center of mass, the elastic parameters of the chassis and tires, which can lead to a significant deterioration of the dynamic characteristics of the armored vehicle. When moving an armored vehicle on a road with a rough surface, it produces forced oscillations, the value of which depends on the dynamic properties of the vehicle, its speed, and the profile of the road surface. An important feature of the armored vehicle is the smoothness of the ride, which determines the comfort of the crew, affects the controllability of the vehicle, improves the accuracy of hitting the target on the move. Road tests require sections of the road with a hard surface and a special controlled profile length of 250 to $1000 \mathrm{~m}$ when driving a vehicle at the speed of 10-90 kph. The characteristics of the road surface are the spectral densities of the microprofile and other indicators that determine the degree of impact of the road on the vehicle. The article analyzes methods for assessing the smoothness of the ride of automotive vehicles. The proposed method for determining the ride smoothness of a vehicle is the frequency method. The dynamic model of free oscillations of the vehicle allows to determine the four frequencies of natural oscillations at full and curb weight. It is recommended to use a low frequency of natural oscillations to assess the smoothness of the ride of the armored vehicle. The calculations were performed for an armored vehicle BRDM-2L1. The results of the calculation allow us to conclude that the proposed theoretical and experimental method can be used at the test stage to assess the smoothness of ride of the armored vehicle, which will significantly reduce the time and cost of its testing.

Keywords: the smoothness of the ride of armored vehicles, the frequency of natural oscillations, a dynamic model of an armored vehicle, the assessment of the smoothness of the ride of armored vehicles. 